\title{
CORROSION RESISTANCE OF AS-PLATED AND HEAT-TREATED ELECTROLESS DUBLEX Ni-P/Ni-B-W COATINGS
}

\author{
KOROZIJSKA ODPORNOST PLATIRANIH IN NEELEKTRIČNO \\ TOPOLOTNO OBDELANIH DUPLEKS Ni-P/Ni-B-W PREVLEK
}

\author{
Behiye Yüksel$^{1}$, Garip Erdogan², Fatih Erdem Bastan², Rasid Ahmed Yıldız \\ ${ }^{1}$ Istanbul Aydin University, Mechanical Engineering Department, 34668 Istanbul, Turkey \\ ${ }^{2}$ Sakarya University, Engineering Faculty, Department of Metallurgy and Materials Engineering, 54187 Sakarya, Turkey \\ ${ }^{3}$ TU Istanbul, Mechanical Engineering Faculty, 34437 Istanbul, Turkey \\ behiyeyuksel@aydin.edu.tr
}

Prejem rokopisa - received: 2016-10-20; sprejem za objavo - accepted for publication: 2017-03-10

doi:10.17222/mit.2016.304

\begin{abstract}
In this study, Ni-P/Ni-B-W dublex coatings were deposited on carbon steel substrates (AISI 1020) using the electroless plating process and their microstructure and corrosion properties were systematically evaluated based on different heat-treatment temperatures. Both, the surface morphology and cross-sectional morphology of the Ni-P/Ni-B-W coatings were studied using a scanning electron microscope (SEM), while X-ray diffraction (XRD) was applied for examining the structural modifications. The amorphous coating began to crystallize at a heat-treatment temperature of $350{ }^{\circ} \mathrm{C}$. Potentiodynamic polarization measurements were carried out in an aqueous medium containing $3.5 \% \mathrm{NaCl}$ for evaluating the corrosion resistance of as-plated and heat-treated dublex coatings. The corrosion potentials of dublex coatings were observed to shift toward more positive values with increased heat-treatment temperatures. Depending on the heat-treatment temperature, it was identified that the crystallized dublex coatings generally had better corrosion resistance than the amorphous coating.

Keywords: Ni-P/Ni-B-W coating, corrosion, heat treatment
\end{abstract}

V študiji so bile dvojne Ni-P/Ni-B-W prevleke nanešene na substrate iz ogljikovega jekla (AISI 1020) s postopkom neelektričnega platiranja. Sistematično so bile ocenjene mikrostruktura ter korozijske lastnosti izdelanih prevlek, glede na različne temperature toplotne obdelave. Morfologije površin in profili izdelanih Ni-P/Ni-B-W prevlek so bili pregledani z vrstičnim elektronskim mikroskopom (SEM), medtem ko so bile z rentgensko difrakcijsko analizo (XRD) ugotovljene strukturne spremembe. Amorfna prevleka je začela kristalizirati pri temperaturi toplotne obdelave $350{ }^{\circ} \mathrm{C}$. Korozijska odpornost platiranih in toplotno obdelanih dupleks prevlek je bila ocenjena s pomočjo meritev potenciodinamične polarizacije v $3,5 \%$ vodni raztopini $\mathrm{NaCl}$. Opazovali so korozijske potenciale dupleks prevlek, da bi dobili bolj pozitivne vrednosti z zvišanimi temperaturami topolotne obdelave. Ugotovljeno je bilo, da imajo kristalizirane dupleks prevleke na splošno boljšo korozijsko odpornost kot amorfne prevleke.

Ključne besede: Ni-P/Ni-B-W dvojna prevleka, korozija, toplotna obdelava

\section{INTRODUCTION}

Studied for the first time in 1946 by Brenner and Riddell, the electroless plating process has been used in many industrial applications because of its superior characteristics over electroplating, such as the ability to plate insulation materials and having a homogeneous coating-thickness distribution. ${ }^{1}$ Among electroless coating types, electroless nickel coating is the most popular for having good hardness, wear and corrosion resistance properties. $^{2}$ If the electroless $\mathrm{Ni}$ coating family is reviewed, besides pure $\mathrm{Ni}$ coatings, Ni-P and Ni-B coatings deposited using reducing agents such as hypophosphite, borohydride or dimethylamine borane stand out. The major advantages of Ni-P coatings are their low cost, high corrosion resistance and easy process control. ${ }^{3}$ Nonetheless, a borohydride reduced nickel coating is harder and has higher wear resistance than tool steel and hard chrome coatings. ${ }^{4,5}$ On the other hand, some studies - although they are limited in number - have highlighted the addition of tungsten to this coating system for in- creasing its corrosion resistance, which is lower than that of a Ni-P coating. ${ }^{6-9}$ As a result of the co-deposition of this refractory material (which cannot be reduced in an aqueous solution as metallic tungsten) together with iron group metals, developing coatings with attractive corrosion and tribological properties is possible..$^{10-12}$ Recently, research for obtaining multilayer coatings to increase existing coating corrosion resistance to higher levels has also been conducted. ${ }^{13,14}$

The aim of the present study was to evaluate the effect of different heat-treatment temperatures on the microstructure and corrosion properties of electroless $\mathrm{Ni}-\mathrm{P} / \mathrm{Ni}-\mathrm{B}-\mathrm{W}$ coatings. To the best of our knowledge, no others studies are available on this topic.

\section{EXPERIMENTAL PART}

For this experiment, $10 \mathrm{~mm} \times 10 \mathrm{~mm} \times 60 \mathrm{~mm}$ plain carbon steel (AISI 1020) plates were used as a substrate material for developing Ni-P/Ni-B-W dublex coatings. Prior to the plating process, the surfaces of all the 


\section{B. YÜKSEL et al.: CORROSION RESISTANCE OF AS-PLATED AND HEAT-TREATED ELECTROLESS ...}

samples were mechanically cleaned (up to 1200 grade) and then soaked in trichloroethylene and cleaned with detergent in an ultrasonic bath at $70{ }^{\circ} \mathrm{C}$. Finally, sample surfaces were activated in $30 \%$ of volume fractions. $\mathrm{HCl}$ for two minutes and then rinsed in distilled water. The cleaned substrates were then soaked in Ni-P and Ni-B-W electroless plating baths for two hours, respectively.

Reagent-grade chemicals and distilled water were used for the preparation of all the electrolytes and the $\mathrm{pH}$ was adjusted to $4.8 \pm 0.2$ and $13.5 \pm 0.2$ with $\mathrm{H}_{2} \mathrm{SO}_{4}$ or $\mathrm{NaOH}$ in Ni-P and Ni-B-W plating baths, respectively. The temperature of the baths was maintained at $90 \pm 2{ }^{\circ} \mathrm{C}$ for Ni-P and $88 \pm 2{ }^{\circ} \mathrm{C}$ for Ni-B-W.

Deposition of Ni-P and Ni-B-W was carried out in an aqueous bath containing $15 \mathrm{~g} / \mathrm{L} \mathrm{NiSO}_{4} \cdot 6 \mathrm{H}_{2} \mathrm{O}, 26 \mathrm{~g} / \mathrm{L}$ $\mathrm{Na}_{2} \mathrm{H}_{2} \mathrm{PO}_{2} \cdot \mathrm{H}_{2} \mathrm{O}, 13 \mathrm{~g} / \mathrm{L} \mathrm{NaC}_{2} \mathrm{H}_{3} \mathrm{O}_{2}, 12 \mathrm{~mL} / \mathrm{L} \mathrm{HF}$ and $8 \mathrm{~g} / \mathrm{L} \mathrm{NH} \mathrm{HF}_{2}$ for the Ni-P coating, and $24 \mathrm{~g} / \mathrm{L} \mathrm{NiCl}{ }_{2}$, $60 \mathrm{~mL} / \mathrm{L}$ EDTA, $26.5 \mathrm{~g} / \mathrm{L} \mathrm{KOH}, 120 \mathrm{~g} / \mathrm{L} \mathrm{NaBH}_{4}$, $263 \mathrm{~g} / \mathrm{L} \mathrm{NaOH}, 2.6 \mathrm{~g} / \mathrm{L} \mathrm{PbWO}_{4}, 13 \mathrm{~g} / \mathrm{L}$ EDTA and $40 \mathrm{~g} / \mathrm{L}$ $\mathrm{Na}_{2} \mathrm{WO}_{4} \cdot 2 \mathrm{H}_{2} \mathrm{O}$ for Ni-B-W coatings, respectively.

The coated specimens were heat treated at $250{ }^{\circ} \mathrm{C}$, $300{ }^{\circ} \mathrm{C}, 350{ }^{\circ} \mathrm{C}$ and $650{ }^{\circ} \mathrm{C}$ for $1 \mathrm{~h}$ each at a heating rate of $5{ }^{\circ} \mathrm{C} / \mathrm{min}$ in an air-circulated furnace, followed by slow furnace cooling to room temperature.

The composition of the dublex coatings was determined by energy-dispersive X-ray analysis (EDX) using a Link Analytical QX-2000 attached to the SEM apparatus. The crystal structures of the dublex coatings were examined using a Philips PW 3710 grazing incidence X-ray diffractometer $\left(\mathrm{Cu}-K_{\alpha}\right.$ radiation). A Jeol JSM-7000F FE-SEM was used to characterize the microstructures and morphology of the coatings. The corrosion behavior was investigated using a PGZ 301 Dynamic Voltammetry and VoltaMaster4 software.

Electrochemical experiments were carried out in a $3.5 \% \mathrm{NaCl}$ aqueous solution in a three-electrode cell at room temperature. In this cell, a platinum electrode was used as a counter electrode and a saturated calomel electrode was used as a reference electrode; the dublex coating was used as a working electrode and by masking

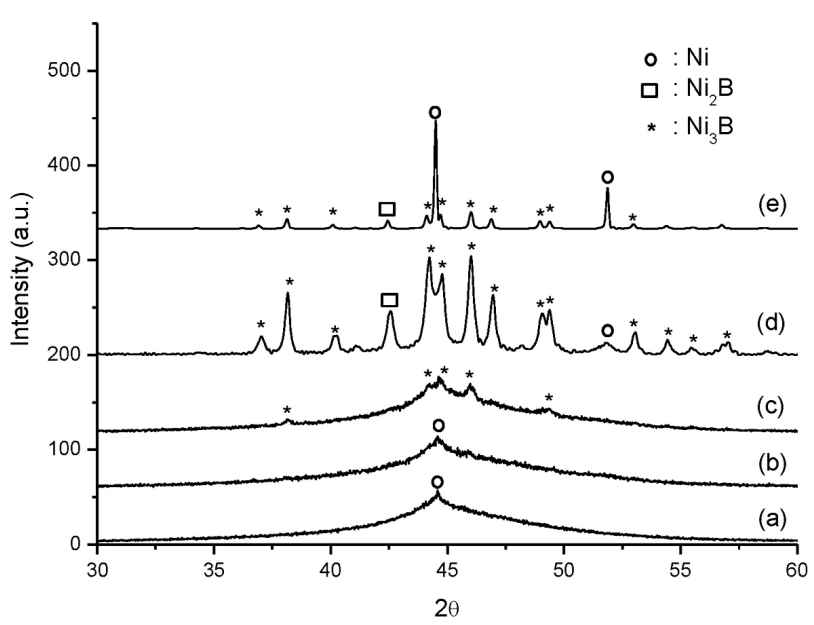

Figure 1: XRD spectra for a): as-plated Ni-P/Ni-B-W, b) $250{ }^{\circ} \mathrm{C}$, c) $300{ }^{\circ} \mathrm{C}$, d) $350{ }^{\circ} \mathrm{C}$ and e) $650{ }^{\circ} \mathrm{C}$ with silicon, only a $1 \mathrm{~cm}^{2}$ surface area was left on the samples for exposure to the electrolyte. The dynamic potential scanning technique was used for obtaining the polarization curves of dublex coating samples. Prior to the potentiodynamic measurement, samples were held for approximately $15 \mathrm{~min}$ in the electrolyte and then electrode potential was raised from $-600 \mathrm{mV}$ to $+200 \mathrm{mV}$ at a rate of $10 \mathrm{mV} / \mathrm{min}$.

\section{RESULTS}

The XRD patterns of the as-plated and heat-treated Ni-P/Ni-B-W coatings, and their chemical compositions are in Figure 1 and in Table 1. SEM micrographs of Ni-P/Ni-B-W coatings before and after the heat treatments are in Figure 2.

Table 1: Chemical compositions of the Ni-P/Ni-B-W dublex coatings

\begin{tabular}{|c|c|c|c|c|}
\hline $\begin{array}{c}\text { Type of } \\
\text { coating }\end{array}$ & $\mathrm{Ni}(w / \%)$ & $\mathrm{P}(w / \%)$ & $\mathrm{B}(w / \%)$ & $\mathrm{W}(w / \%)$ \\
\hline $\mathrm{Ni}-\mathrm{P}$ & 87.27 & 12.73 & - & - \\
\hline Ni-B-W & 87.45 & - & 7.86 & 4.69 \\
\hline
\end{tabular}

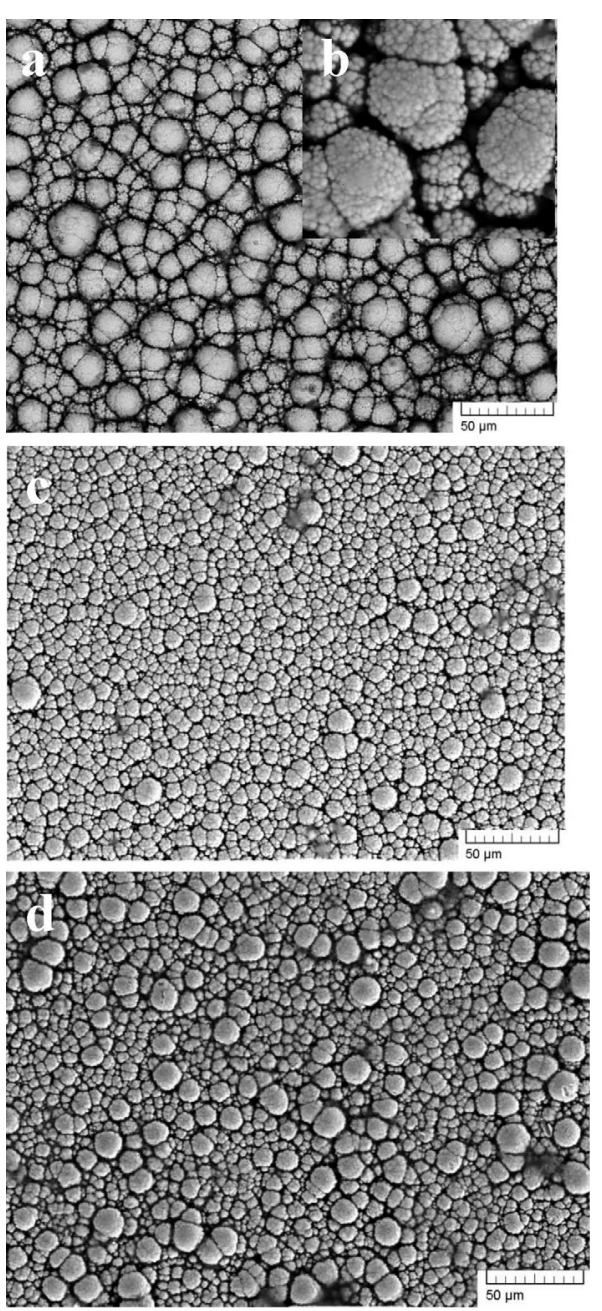

Figure 2: Surface morphology of dublex coating a), b) as-plated $\mathrm{Ni}-\mathrm{P} / \mathrm{Ni}-\mathrm{B}-\mathrm{W}, \mathrm{c}$ ) heat treated at $300{ }^{\circ} \mathrm{C}$, d) heat treated at $650{ }^{\circ} \mathrm{C}$ 

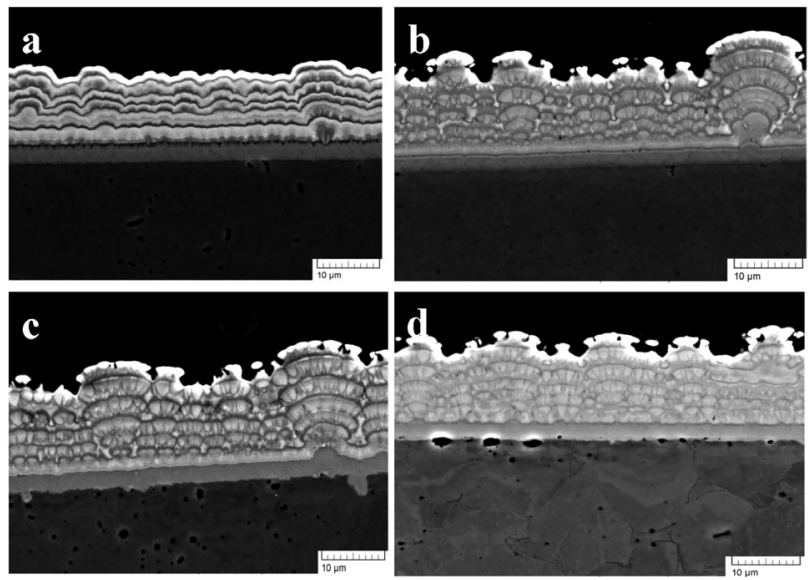

Figure 3: Cross-section of Ni-P/Ni-B-W dublex coating: a) as-plated, b) heat treated at $250{ }^{\circ} \mathrm{C}$ c) heat treated at $350{ }^{\circ} \mathrm{C}$, d) heat treated at

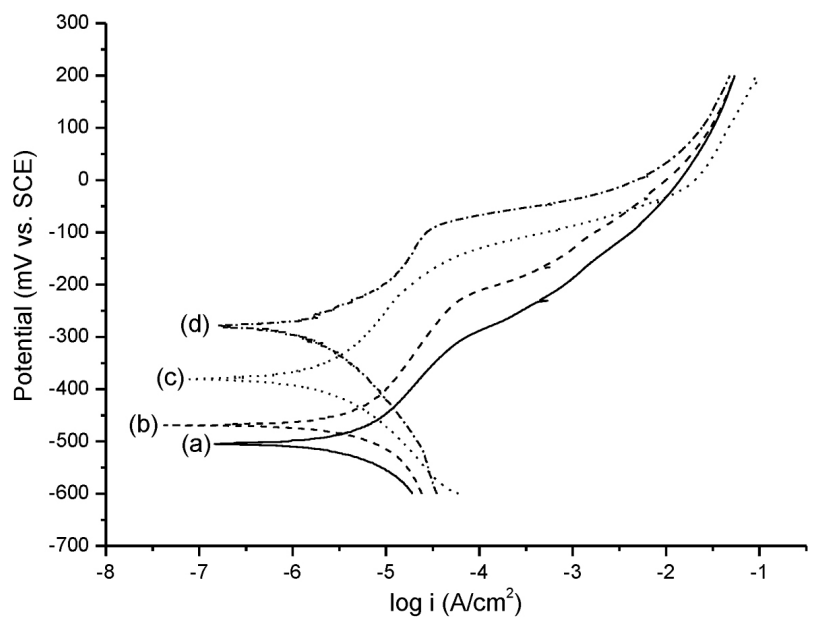

Figure 4: Polarization curves in a $3.5 \% \mathrm{NaCl}$ aqueous medium of as-plated and heat-treated Ni-P/Ni-B-W coatings: a) as-plated $\mathrm{NiP} / \mathrm{NiBW}, \mathrm{b}$ ) heat treated at $300{ }^{\circ} \mathrm{C}$, c) heat treated at $350{ }^{\circ} \mathrm{C}$ d) heat treated at $650{ }^{\circ} \mathrm{C}$

The cross-sections of the Ni-P/Ni-B-W dublex coatings are shown in Figure 3.

Potentiodynamic curves of as-plated and heat-treated $\mathrm{Ni}-\mathrm{P} / \mathrm{Ni}-\mathrm{B}-\mathrm{W}$ coatings at different temperatures obtained in a $3.5 \% \mathrm{NaCl}$ aqueous medium are shown in Figure 4.

The changes in the corrosion current density $\left(I_{\text {corr }}\right)$ values with heat treatment are given in Table 2.

Table 2: Corrosion resistance of as-plated and heat-treated $\mathrm{Ni}-\mathrm{P} / \mathrm{Ni}-\mathrm{B}-\mathrm{W}$ dublex coatings at different temperatures in $3.5 \% \mathrm{NaCl}$ solution

\begin{tabular}{|c|c|c|}
\hline $\mathrm{NiP} / \mathrm{NiBW}$ & $I_{\text {corr }}\left(\mu \mathrm{A} / \mathrm{cm}^{2}\right)$ & $E_{\text {corr }}(\mathrm{mV})$ \\
\hline As-plated & $1.55 \pm 0.59$ & $-506 \pm 32$ \\
\hline $300{ }^{\circ} \mathrm{C}$ & $1.70 \pm 0.41$ & $-470 \pm 23$ \\
\hline $350{ }^{\circ} \mathrm{C}$ & $0.71 \pm 0.20$ & $-382 \pm 18$ \\
\hline $650{ }^{\circ} \mathrm{C}$ & $0.57 \pm 0.09$ & $-280 \pm 11$ \\
\hline
\end{tabular}

The surface morphologies of the as-plated sample and heat-treated sample at $650{ }^{\circ} \mathrm{C}$ following potentio-
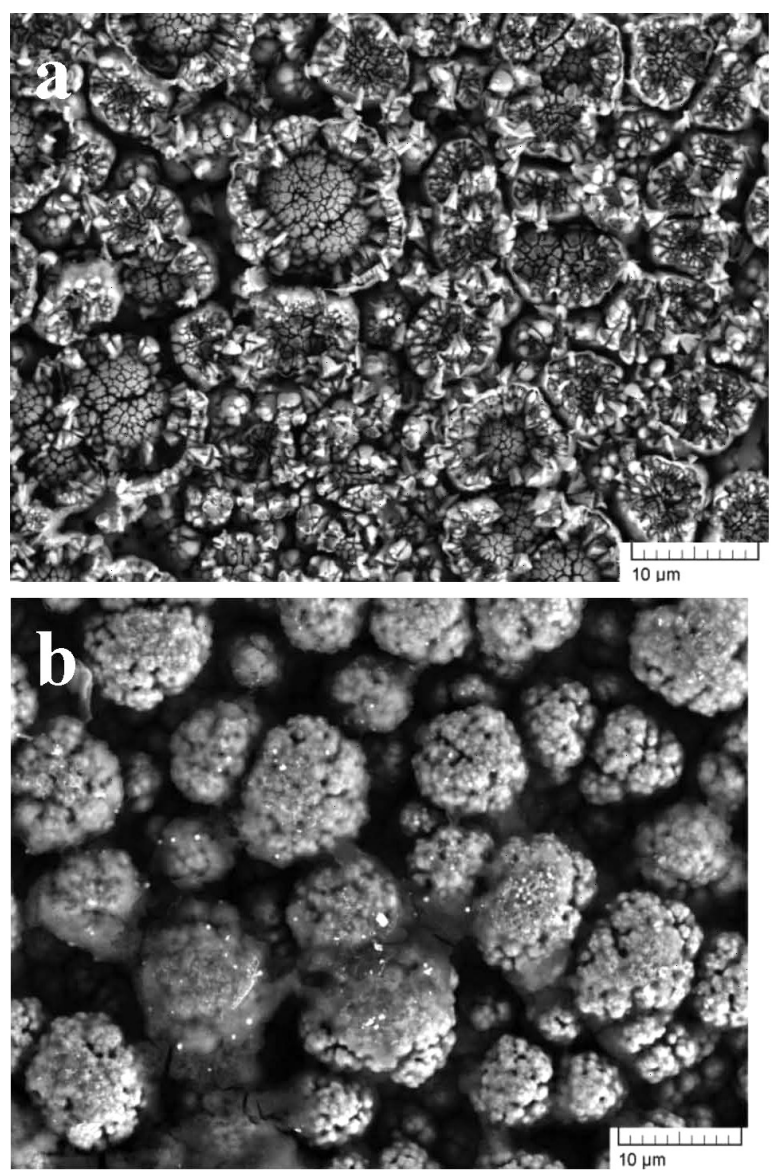

Figure 5: Surface morphology of NiP/NiBW dublex coatings detected by SEM after potentiodynamic measurement: a) as-plated, b) heat treated at $650{ }^{\circ} \mathrm{C}$

dynamic polarization measurements are shown in Figure 5.

The corrosion current density and corrosion potential values obtained by Tafel interpolation are shown in Table 3.

Table 3: Corrosion resistance of substrate and Ni-B-W and $\mathrm{Ni}-\mathrm{P} / \mathrm{Ni}-\mathrm{B}-\mathrm{W}$ dublex coatings heat treated at $650{ }^{\circ} \mathrm{C}$ in $3.5 \% \mathrm{NaCl}$ solution

\begin{tabular}{|c|c|c|}
\hline Sample & $I_{\text {corr }}\left(\mu \mathrm{A} / \mathrm{cm}^{2}\right)$ & $E_{\text {corr }}(\mathrm{mV})$ \\
\hline $\begin{array}{c}\text { Carbon steel } \\
\text { substrate }\end{array}$ & $4.59 \pm 1.01$ & $-598 \pm 46$ \\
\hline NiBW & $3.40 \pm 0.35$ & $-298 \pm 17$ \\
\hline NiP/NiBW & $0.57 \pm 0.09$ & $-280 \pm 11$ \\
\hline
\end{tabular}

Figure 6 shows the polarization curves of the Ni-B-W and dublex Ni-P/Ni-B-W coatings heat treated at $650{ }^{\circ} \mathrm{C}$ and the steel substrate obtained in a $3.5 \%$ $\mathrm{NaCl}$ aqueous medium.

\section{DISCUSSION}

The Ni-P/Ni-B-W coating diffraction patterns up to $300{ }^{\circ} \mathrm{C}$ reveal a single broad peak indicating an amorphous coating structure under these conditions (Fig- 
B. YÜKSEL et al.: CORROSION RESISTANCE OF AS-PLATED AND HEAT-TREATED ELECTROLESS ...

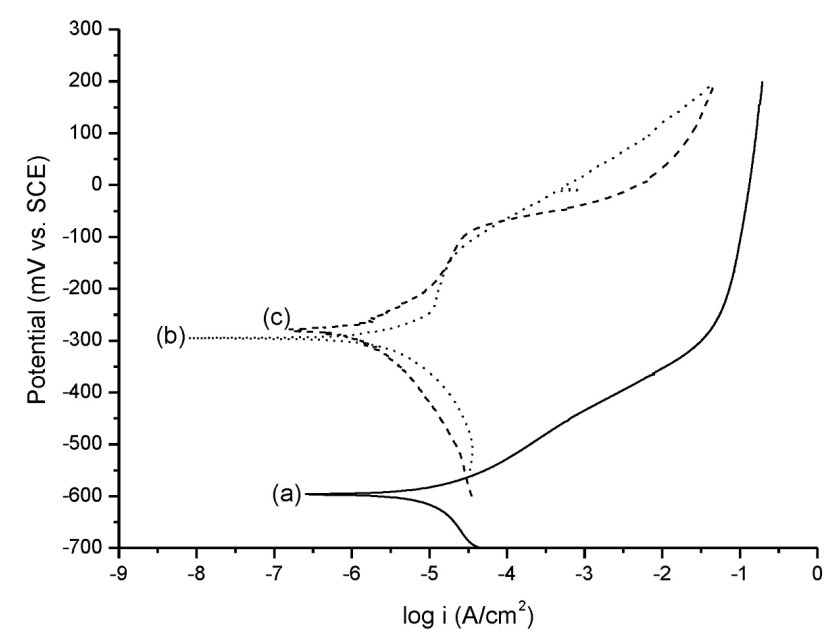

Figure 6: Polarization curves: a) steel substrate, b) Ni-B-W coating heat treated at $650{ }^{\circ} \mathrm{C}, \mathrm{c}$ ) dublex Ni-P/Ni-B-W coating heat treated at $650{ }^{\circ} \mathrm{C}$

ure 1). For heat-treatment temperatures up to $300{ }^{\circ} \mathrm{C}$, the dublex coating preserved its amorphous structure. However, after heat treatment at and above $300{ }^{\circ} \mathrm{C}$, the diffraction patterns showed the formation of $\mathrm{Ni}_{3} \mathrm{~B}$ intermetallic crystals. For the higher heat-treatment temperatures up to $650{ }^{\circ} \mathrm{C}$, formation of the nickel borides progressively increased. Drovosekov et al., reported chemical bond formations between boron and tungsten in the Ni-B-W coating system. However, the major nickel borides formed during the heat treatments might have prevented the formation of the B-W bond. ${ }^{9,15}$ In other words, the quantity of the boron in the coating was high enough to prevent the formation of Ni-W compounds in the structure. ${ }^{16}$

SEM micrographs of the Ni-P/Ni-B-W coatings before and after the heat treatments showed the formation of typical spherical nodular structures (Figure 2). Each nodule appears to be formed by the unification of many grains existing as colonies (Figure 2b), similar to the case suggested by S. Ruan et al. ${ }^{17}$ Some microcracks were noticeable on the surfaces of the as-plated Ni-P/Ni-B-W samples. The microcracks may be due to the internal stress caused by the relatively larger tungsten atoms in the coating structure. ${ }^{18,19}$

With the heat treatments, the structure progressively crystallized and, as consequence, a substantial reduction of the microcracks was noticed (Figure $\mathbf{2 c}$ and $\mathbf{2 d}$ ). In a Ni-B-W coating system, $\mathrm{W}$ atoms may selectively exist at the boundaries of the nodules, from there, they may segregates to the coating surface, during the heat treatments. ${ }^{16,17}$ This process may decrease the internal stress inside the coating, resulting in a substantial decrease of the microcracks on the coating surface.

The thickness of the Ni-P coating in the dublex coating system was measured as $2 \mu \mathrm{m}$, while the average thickness of the Ni-B-W (the other coating in the system) was measured as $11 \mu \mathrm{m}$ (Figure 3). On the other hand, it was obvious that the nodular structure seen in the surface morphology of the Ni-B-W coating showed columnar growth starting from the Ni-P layer to the topmost surface of the coating (Figure 3a). Furthermore, it was observed that adherence of the $\mathrm{Ni}-\mathrm{P}$ coating to the substrate was good and there was no pore formation between the substrate and Ni-P coating. Pores seen in the interface of $\mathrm{Ni}-\mathrm{P} / \mathrm{Ni}-\mathrm{B}-\mathrm{W}$, in addition to pores partially observed inside the Ni-B-W coating had a columnar structure and they were considered to have been formed due to the capturing of released hydrogen - even if in small amounts - during the oxidation reaction of sodium borohydride used as a the boron source. ${ }^{5}$ The pores disappear with increasing heat-treatment temperatures. This may be a result of the diffusion of hydrogen atoms to the surface. They may promote better crystallization of the coating and ease the formation of the $\mathrm{Ni}_{3} \mathrm{~B}$ and $\mathrm{Ni}_{2} \mathrm{~B}$ phases (Figure 3b and 3c). After $650{ }^{\circ} \mathrm{C}$ heat treatment the major phase of the coating was noticed to be $\mathrm{Ni}_{3} \mathrm{~B}$. At that stage adherence between the coatings reached its best level, while the Ni-B-W coating showed columnar grains with a denser structure (Figure 3d).

As Figure 4, a difference of approximately $220 \mathrm{mV}$ was detected between corrosion potentials $\left(E_{\text {corr }}\right)$ of as-plated and $650{ }^{\circ} \mathrm{C}$ heat-treated dublex coatings. This is the shifting of $E_{\text {corr }}$ values of the coatings toward nobler values with increased heat treatments applied to the coatings. The anodic branch of the polarization curve of the coating before heat treatment showed the breakdown potential at values around $-310 \mathrm{mV}$ (Figure 4a). But the current density increased at a constant rate, indicating that the unstable passive film formation on the coating has disappeared rapidly. For heat treatment at $300{ }^{\circ} \mathrm{C}$, the breakdown potential was observed to shift toward $-220 \mathrm{mV}$. At $300{ }^{\circ} \mathrm{C}$, which is the onset temperature of crystallization, corrosion potential shifted towards a positive end approximately $40 \mathrm{mV}$, compared to the as-plated sample. At $350{ }^{\circ} \mathrm{C}$, crystallization was nearly completed and the corrosion potential had shifted towards more positive values. However, the breakdown potential was observed (as with other samples) at around $-180 \mathrm{mV}$. Nonetheless, it was detected that the current density of this sample became higher as the potential value increased compared with that for the to as-plated and heat-treated samples at $300{ }^{\circ} \mathrm{C}$. For the heat treatment at $650{ }^{\circ} \mathrm{C}$, a passive film formation on the coating surface was seen at around $-190 \mathrm{mV}$, suggesting that corrosion rate was restrained at such potential range. However, as this protective film began to dissolve at around $-90 \mathrm{mV}$, a steep increase in the current density was observed.

The major reason for the difference between the corrosion resistance of as-plated and heat-treated Ni-P/Ni-B-W coatings exposed to chloride ions was undoubtedly associated with the transformation of the microstructure from an amorphous to a crystalline morphology. The main reason for having a higher $E_{\text {corr }}$ value the heat-treated coating at $300{ }^{\circ} \mathrm{C}$ (where an amorphous 


\section{B. YÜKSEL et al.: CORROSION RESISTANCE OF AS-PLATED AND HEAT-TREATED ELECTROLESS ...}

structure still prevailed) compared to the as-plated sample was the result of the borides formed during the onset of crystallization. The heat-treated sample at $350{ }^{\circ} \mathrm{C}$ (where the microstructure had completely been transformed to a crystalline structure) had a higher corrosion resistance compared to the sample heat-treated at $300{ }^{\circ} \mathrm{C} .{ }^{20}$ On the other hand, it is a known fact that corrosion resistance generally increases with addition of tungsten to a electroless nickel-boron coating system, because of the tendency to form an oxide film on the surfaces. ${ }^{7,18}$ However, as seen in Figure 4, the corrosion resistance of the as-plated Ni-P/Ni-B-W sample having a nodular structure did not increase, with the addition of tungsten. This is because the tungsten atoms were stuck in the colony boundaries, not to be segregated to the surfaces during the corrosion process and therefore, could not be oxidized to promote the formation of a mixed oxide film. However, depending on the increased heat treatment temperatures segregation of $\mathrm{W}$ atoms toward surfaces at $650{ }^{\circ} \mathrm{C}$ was more likely to occur. The mixed oxide film a passive zone formed this way may be the main reason for the substantial decrease of the current density as observed here.

It can be seen that uniform corrosion occurred on the surface of the as-plated sample in the amorphous structure that has the lowest corrosion resistance (Figure 5a). Conversely, on the surface of the heat-treated sample at $650{ }^{\circ} \mathrm{C}$ complete crystallization were noted and the pits (indicated by arrows) in the grains within the colonies were observed (Figure 5b).

To interpret the effect of the dublex coating on corrosion resistance, the potentiodynamic polarization measurements of the Ni-P/Ni-B-W and Ni-B-W coatings, as well as which were deposited under the same process conditions and heat-treated at $650{ }^{\circ} \mathrm{C}$, and carbon steel substrate were studied (Table 3).

As can be observed from Figure 6, while the Ni-B-W coating and the dublex coating almost had the same corrosion potential, more positive values at about 300 $\mathrm{mV}$, compared with that of the substrate. Among the coating studied the dublex coating has the lowest corrosion current density. The anodic branches of polarization curves of both the dublex and the Ni-B-W coatings have a passive zone, and both coatings had an $E_{\text {pit }}$ value of approximately $-90 \mathrm{mV}$. Additionally, the current density of the Ni-B-W coating at a constant rate increases, depending on the increased potential value. On the other hand, the anodic branch of the dublex coating indicated that an entrance to a second passive zone at approximately $20 \mathrm{mV}$. This passive zone may be related to the existence of Ni-P in the dublex coating. A similar interpretation was reported by Zhang et al. for the corrosion of Ni-B-W surfaces. ${ }^{14}$ In general, corrosion starts at the outermost surface of the substrate and proceed inward. However, the stable passive film formed on the Ni-P layer on the substrate may act as a barrier for corrosion propagation, causing the dublex coating to have better corrosion resistance than the single-layer $\mathrm{Ni}-\mathrm{B}-\mathrm{W}$ coating.

\section{CONCLUSIONS}

The effect of heat treatments on the corrosion resistance of a Ni-P/Ni-B-W dublex coating deposited on carbon steel was studied. The Ni-P/Ni-B-W coatings have an amorphous structure for a heat treatments up to $300{ }^{\circ} \mathrm{C}$. The coatings start to crystallize at about $350{ }^{\circ} \mathrm{C}$ and completed at about $650{ }^{\circ} \mathrm{C}$ with the major phases being the nickel borides. The heat treatment, besides causing nickel boride formation within Ni-B-W, also caused obtaining a denser Ni-P/Ni-B-W coating when increasing heat treatment temperature.

The corrosion resistance of the dublex coating increases substantially with increasing the heat treatment temperature. The dublex coating and the single-layer $\mathrm{Ni}-\mathrm{B}-\mathrm{W}$ coating heat-treated at $650{ }^{\circ} \mathrm{C}$ indicated higher corrosion resistance as compared to that of steel substrate. When these two coatings were compared in terms of corrosion resistance, the dublex coating showed better performance.

\section{REFERENCES}

${ }^{1}$ A. Brenner, G. Riddell, Nickel Plating on Steel by Chemical Reduction, J. Res. Nat. Bur. Std., 37 (1946), 31-35

${ }^{2}$ J. Sudagar, J. Lian, W. Sha, Electroless nickel, alloy, composite and nano coatings-A critical review, J. Alloys Compd., 571(2013), 183-204, doi:10.1016/j.jallcom.2013.03.107

${ }^{3}$ Y. F. Shen, W.Y. Xue, Z.Y. Liu, L. Zuo, Nanoscratching Deformation and Fracture Toughness of Electroless Ni-P Coatings, Surf. Coat. Technol., 205 (2010), 632-640, doi:10.1016/j.surfcoat.2010.07.066

${ }^{4}$ K. M. Gorbunova, M.V. Ivanov, V. P. Moissev, Electroless Deposition of Nickel-Boron Alloys - Mechanism of Process, Structure, and Some Properties of Deposits, J. Electrochem. Soc., 120 (1973), 613-618, doi:10.1149/1.2403514

${ }^{5}$ R. N. Duncan, T. L. Arney, Operation and Use of Sodium-Borohydride-Reduced Electroless Nickel, Plat. Surf. Finish., 71 (1984) 12, 49-54

${ }^{6}$ R. A. C. Santana, S. Prasad, A. R. N. Campos, F. O. Arau' jo, G. P. DA Silva, P. Lima-Neto, Electrodeposition and Mechanical Properties of Ni-W-B Composites from Tartrate Bath, Prot Met Phys Chem., 46 (2010) 1, 117-122, doi:10.1134/S207020511001017X

${ }^{7}$ M. G. Hosseini, M. Abdolmaleki , H. Ebrahimzadeh, S. A. Seyed Sadjadi, Effect of 2-Butyne-1, 4-Diol on the Nanostructure and Corrosion Resistance Properties of Electrodeposited Ni-W-B Coatings, Int. J. Electrochem. Sci., 6 (2011) 4, 1189-1205

${ }^{8}$ T. Osaka, N. Takano, T. Kurokawa, T. Kaneko, K. Ueno, Characterization of chemically-deposited $\mathrm{NiB}$ and NiWB thin films as a capping layer for ULSI application, Surf. Coat. Technol., 169-170 (2003), 124-127, doi:10.1016/S0257-8972(03)00186-5

${ }^{9}$ G. Graef, K. Anderson, J. Groza, A. Palazoglu, Phase evolution in electrodeposited Ni-W-B alloy, Mater. Sci. Eng., B41 (1996), 253-257, doi:10.1016/S0921-5107(96)01656-X

${ }^{10}$ E. Lassner, W. D. Schubert, Tungsten: Properties, Chemistry, Technology of the Element, Alloys, and Chemical Compounds, Kluwer Academic, New York, 1999

${ }^{11}$ E. Beltowska-Lehman, Kinetics of Induced Electrodeposition of Alloys Containing Mo from Citrate Solutions, Phys. Stat. Sol., 5 (2008) 11, 3514-3520, doi:10.1002/pssc.200779404 


\section{MATERIALI IN TEHNOLOGIJE/MATERIALS AND TECHNOLOGY (1967-2017) - 50 LET/50 YEARS}

B. YÜKSEL et al.: CORROSION RESISTANCE OF AS-PLATED AND HEAT-TREATED ELECTROLESS ...

${ }^{12}$ A. I. Aydeniz, A. Göksenli, G. Dil, F. Muhaffel, C. Calli, B. Yüksel, Electroless Ni-B-W Coatings for Improving Hardness, Wear And Corrosion Resistance, MTAEC9, 47 (2013) 6, 803-806

${ }^{13}$ T. S. N. Sankara Narayanan, K. Krishnaveni, S. K. Seshadri, Electroless Ni-P/Ni-B Dublex Coatings: Preparation and Evaluation of Microhardness, Wear and Corrosion Resistance, Mater. Chem. Phys. 82 (2003), 771-779, doi:10.1016/S0254-0584(03)00390-0

${ }^{14}$ W. X. Zhang, Z. H. Jiang, G. Y. Li, Q. Jiang, J. S. Lian, Electroless NiP/NiB Dublex Coatings For Improving The Hardness and The Corrosion Resistance of AZ91 D Magnesium Alloy, Appl. Surf. Sci., 254 (2008), 4949-4955, doi:10.1016/j.apsusc.2008.01.144

${ }^{15}$ A. B. Drovosekov, M.V. Ivanov, V. M. Krutskikh, E. N. Lubnin, Y. M. Polukarov, Chemically Deposited Ni-W-B Coatings: Composition, Structure and Properties, Prot. Met., 41(2005) 1, 55-62, doi:10.1007/s11124-005-0008-1

${ }^{16}$ F. Z. Yang, Z. H. Ma, L. Huang, S. K. Xu, S. M. Zhou, Electrodeposition and Properties of an Amorphous Ni-W-B Alloy before and after Heat Treatment, Chin. J. Chem., 24 (2006), 114-118, doi:10.1002/cjoc.200690004
${ }^{17}$ S. Ruan, C. A. Schu, Mesoscale Structure and Segregation in Electrodeposited Nanocrystalline Alloys, Scripta Mater., 59 (2008) 11, 1218-1221, doi:10.1016/j.scriptamat.2008.08.010

${ }^{18}$ R. A.C. Santana, S. Prasad, A. R. N. Campos, F. O. Arau' jo, G.P. Silva, P. Lima-Neto, Electrodeposition and Corrosion Behaviour of a Ni-W-B Amorphous Alloy, J. Appl. Electrochem., 36 (2006), 105-113, doi:10.1007/s10800-005-9046-2

${ }^{19}$ R. A. Yildiz, A. Göksenli, B. Yüksel, F. Muhaffel, A. Aydeniz, Effect of Annealing Temperature on The Corrosion Resistance of Electroless Produced Ni-B-W Coatings, Adv Mat Res., 652 (2013), 263-268, doi:10.4028/www.scientific.net/AMR.651.263

${ }^{20}$ Z. Z. Hamid, H. B. Hassan, A. M. Attyia, Influence of Deposition Temperature and Heat Treatment on The Performance of Electroless Ni-B Films, Surf. Coat. Technol., 205 (2010) 7, 2348-2354, doi:10.1016/j.surfcoat.2010.09.025 